\title{
The influence of civil society on Ukrainian anti- corruption policy after the Maidan
}

\begin{abstract}
This article examines the influence of civil society on Ukrainian anti-corruption policy after the Maidan in 2014. Drawing on the Advocacy Coalition Framework (ACF), we hypothesise that the Maidan events led to a redistribution of formal legal authority in the anti-corruption policy subsystem, opened access to policy venues for civil society actors, and increased leverage of international organisations to push for strict reforms. We test these expectations with a systematic content analysis of primary documents and semi-structured interviews. Findings show that changes in the formal legal authority to make policy decisions led to anti-corruption policy change. The newly adopted policies were largely influenced by civil society actors who had increased venue access after the Maidan. In addition, civil society advocated for strict anti-corruption reforms through international organisation.
\end{abstract}

KEYWORDS: Anti-corruption policy, Advocacy Coalition Framework, civil society, Ukraine.

RECEIVED 26 March 2020; ACCEPTED 15 December 2020.

\section{INTRODUCTION}

In 2014, Ukrainian experts and scholars founded a network of civil society organisations called the Reanimation Package of Reforms (RPR). The network coordinates the work of 83 non-governmental organisations (NGOs). The RPR network provides action plans for key reforms of the public sector in Ukraine and takes the role of a watchdog during their implementation process. Core topics of the reforms advocated by the RPR network encompass anti-corruption, decentralization and public administration.

This article examines how civil society actors of the RPR have influenced Ukrainian anti-corruption policy after the Maidan events in 2014. We draw on the Advocacy Coalition Framework (ACF) (Jenkins-Smith, Nohrstedt, Weible, \& Ingold, 2017; Sabatier, 1987) to trace the influence of the RPR on key anti-corruption reforms and on the implementation of these reforms. The ACF argues that shocks can generate policy change through a redistribution of coalitions' resources and by changing the conditions to access policy venues (Sabatier and Weible, 2007, p. 199). We argue that the events of the Maidan in Kyiv consisted of a shock that led to both a redistribution of resources among coalitions and a change in policy venue access for civil society actors. Most importantly, the Maidan transferred the most important political resource, the formal legal authority to make policy decision to a pro-reform coalition comprising the RPR. In addition, the crisis following the Maidan increased the leverage of international organisations such as the European Union (EU) or the International Monetary Fund (IMF) on the Ukrainian government. The RPR strategically used the newly gained access to policymaking venues and the increased leverage of international actors to advocate for enhanced anti-corruption policies.

With this article, we aim to contribute to the body of literature on the influence of civil society on policy making, to studies on Ukrainian anti-corruption policy, as well as to the ACF literature. There is a large body of literature focusing on anti-corruption policy more broadly (e.g., Persson, Rothstein \& Teorell, 2012) and studies on Ukrainian anti-corruption policy more specifically (Grodeland, 2010; Denisova-Schmidt, Huber, \& Leontyeva, 2016). However, only a few recent studies focus on the role of civil society in the anti-corruption policy subsystem in Ukraine (Harasymiw, 2019; Zaloznaya, Reisinger, \& Claypool, 2018).

In the growing body of research applying the ACF to explain policy change, there are only a few applications to Central and Eastern Europe (e.g., Poljak, 2018; Albright 2011). Moreover, we contribute to the ACF by shedding light on the role that international actors can play in domestic coalitions. The role of international organisations in domestic advocacy coalitions remains

1 National Research University Higher School of Economics, Public Policy Department

2 National Research University Higher School of Economics, Public Policy Department 
an under-researched topic in the ACF (for an exception, see Kukkonen et al., 2018), and literature on policy advice of international organisations on domestic policy does not refer to the ACF (Fang \& Stone, 2012; Schlaufer, 2019).

Methodologically, we rely on a systematic analysis of policy documents and reports by the RPR network, expert reports, as well as of EU, IMF, and OECD international donor reports. Changes in anti-corruption policy are examined through an analysis of Ukrainian legislation. In addition, we conducted semi-structured interviews with experts and stakeholders of the anti-corruption policy subsystem in Ukraine to triangulate the findings from the document analysis.

The remainder of the article is structured as follows. First, we outline the theoretical framework and deduce expectations for the Ukrainian anti-corruption policy case. The methodological section describes the procedure of data collection and analysis. Subsequently, the findings are presented and their implications for the involvement of civil society in the Ukrainian anti-corruption policy are discussed. The article concludes with a short discussion of the contributions of the inquiry for the ACF.

\section{THEORETICAL FRAMEWORK: THE ADVOCACY COALITION FRAMEWORK}

The ACF examines how actors attempt to influence policy in a specific policy subsystem (Jenkins-Smith et al., 2017; Sabatier, 1987; Sabatier \& Jenkins-Smith, 1994). The policy subsystem is the main unit of analysis of the ACF. Policy subsystems are defined by the substantial focus on a policy topic, territorial boundaries, and the different actors that regularly attempt to influence policy in the subsystem (such as governmental officials, legislators, civil society representatives, think tanks, and researchers) (Jenkins-Smith et al., 2017, p. 139).

According to the ACF, actors form so-called advocacy coalitions to influence policy in the subsystem. In a subsystem, typically two (but sometimes up to four) advocacy coalitions form to advocate for their preferred policy preferences. Actors are organised into advocacy coalitions on the basis of two criteria: 1) actors share common beliefs and 2) actors coordinate their strategies to influence policy (Jenkins-Smith et al., 2017).

The ACF separates the first criteria, belief systems, into three different categories: First, core beliefs, which are hard to change and encompass fundamental beliefs. Second, policy core belief, which are also not easily changeable, but are restricted to a policy subsystem. Policy core beliefs include basic value priorities within the policy subsystem such as perception of the causes of policy problems and preferred solutions for the problem. The third and most easily changeable belief set constitutes secondary beliefs that deal with the subcomponents of the policy subsystem or specific tools to achieve goals. (Jenkins-Smith et al., 2017; Jenkins-Smith \& Sabatier, 1994). The second criterion, coordination, maintains that actors who share policy beliefs coordinate their activities, either strongly or weakly (Weible et al., 2019).

Coordination of actors inside a coalition can, for example, take the form of sharing resources to influence policymaking. Advocacy coalitions exploit political resources to strategically influence policy in the subsystem. Political resources of coalitions include formal legal authority to make policy decisions; public opinion; information; mobilizable supporters; financial resources; and skilful leadership (Sabatier \& Weible, 2007, pp. 198-201). Nohrstedt (2011) and Heinmiller $(2013,2016)$ argue that some political resources are more influential than others to influence public policy. A unique status among coalition resources has formal legal authority to make policy decisions. To have coalitional members in a position with formal legal authority is a decisive coalition resource unlike others (Nohrstedt, 2011; Heinmiller, 2013, 2016).

The main goal of the ACF is to explain policy change. The ACF proposes two hypotheses of policy change. The main focus of ACF studies is the first hypothesis that defines significant perturbations external or internal to the policy subsystem, policy-oriented learning, or negotiated agreement as a necessary but not sufficient condition for policy change. The second hypothesis states that policy will not be significantly changed as long as the advocacy coalition that instated the policy remains in power (Jenkins-Smith et al., 2017, p. 147). This second hypothesis has been tested only a few times by scholars focusing on explaining policy stasis alongside policy change (e.g., Hirschi and Widmer, 2010; Kübler, 2001). ${ }^{3}$

3 The focus of the present study is the first policy change hypothesis. The second policy change hypothesis would require an examination of the question of why anti-corruption policy did not change before the Maidan. Such an analysis is beyond the scope of this article that focuses on the influence of civil society actors on anti-corruption policy after the Maidan. However, our research highlights the importance of new actors coming to power for policy change. We examine this aspect in the context of the first policy change hypothesis, arguing that a perturbation led to a redistribution of legal authority as the most important coalition resource allowing for anti-corruption policy change. 
Concerning the first hypothesis, an important role in policy change play perturbations or shocks such as a change in socioeconomic conditions, regime change, crises, or disasters (Jenkins-Smith et al., 2017, p. 145). Such events increase the likelihood of policy change, but they are not sufficient to generate policy change alone. The ACF points to several mechanisms leading from a perturbation to policy change: large-scale events may affect the structures of coalitions, the distribution of the resources of the coalitions, or they may alter the conditions for accessing important policy venues (Albright, 2011; Nohrstedt, 2011). An important mechanism is thereby the redistribution of political resources among coalitions. A perturbation may change the coalition resources to such an extent that the previously minority coalition becomes the dominant coalition in a subsystem. In this case, the most powerful resource, the formal legal authority, is transferred to members of the previous minority coalition (Jenkins-Smith et al., 2017, p. 155; Nohrstedt, 2011). Alternatively, members of minority coalitions or actors, who had previously been excluded from the policy process, may skilfully exploit such perturbations to access new policy venues and have an influence on public policy (Albright, 2011).

To answer our research question of how civil society actors of the RPR have influenced Ukrainian anti-corruption policy after the Maidan, we assume that the Maidan events consisted of a dramatic perturbation of Ukrainian politics and society, and this perturbation led to policy change. We expect that the main mechanism for policy change was that the Maidan transferred the legal authority to make policy decisions to a reform coalition that comprised the civil society actors of the PRP. Thus, the following expectation is drawn from the ACF policy change hypothesis for our case:

Expectation 1: Through the Maidan, the coalition that includes the civil society actors of the RPR gained legal authority to make policy decisions leading to a change in anti-corruption policy.

To answer our research question, we also need to examine how civil society actors of the RPR advocated their preferred anticorruption policy inside the pro-reform coalition. Anti-corruption literature points to the importance of civil society actors for anticorruption reforms. Literature suggests that those actors with the legal authority to adopt and implement anti-corruption policies (namely, members of government and parliaments, as well as high-level civil servants) have weak or negative incentives to do so, as these elite actors often benefit from corruption (Abdulai, 2009; Fritzen, 2005; Stapenhurst \& Langseth, 1997). This dilemma is made responsible for a variety of unsuccessful anti-corruption reforms, including for the failures of governments that come to power with the promise of fighting corruption. To resolve this dilemma, literature points to the importance of a strong civil society (De Sousa, Hindess, and Larmour, 2012; Mingiu-Pippidi, 2010, 2015). Civil society actors usually advocate for stricter anti-corruption policy than governmental actors do, and they play an important role in overseeing implementation of policies.

Drawing on this literature, we assume that the change in government following the Maidan cannot solely explain anti-corruption policy change. We expect that civil society actors advocating for stricter reforms played an important role. To successfully advocate for stricter anti-corruption policy inside the reform coalition, the RPR needed access to policy venues. The ACF maintains that external perturbations may also open policymaking venues for new actors (Albright, 2011; Jenkins-Smith et al., 2017; Nohrstedt, 2011). We, therefore, expect that:

\section{Expectation 2: The Maidan events increased venue access for civil society actors of the RPR.}

In addition, sustained pressure of international organisations can assist in pressuring governmental actors towards anti-corruption reforms. International organisations can influence national anti-corruption policy through a variety of positive and negative incentives, such as the provision or withdrawal of financial aid or the imposition of sanctions (Heineman \& Heimann, 2006). We expect that the Maidan increased pressure and leverage of international organisations on Ukrainian policymakers to adopt anti-corruption policies. Civil society actors could, therefore, not only directly advocate for their policy preferences through increased access to governmental policy venues, but also indirectly through collaborating with international organisations.

Expectation 3: Civil society actors of the RPR advocated anti-corruption policies also through international organisations, who had increased leverage to influence policy after the Maidan. 


\section{METHODOLOGICAL APPROACH}

Research design: We rely on a single case study design to examine our expectations. Policy change in the Ukrainian anti-corruption policy subsystem after the Maidan is seen as a typical case of policy change after a major event (Gerring, 2007, p. 91-93; Seawright and Gerring, 2008). Typical cases provide valuable insights about what processes and causal mechanisms lead to a certain outcome (Bennett, 2004; George \& Bennett, 2004).

Data collection: The case study draws primarily on a systematic document analysis and uses semi-structured interviews to illustrate the findings from the document analysis. The documents included in the analysis consist of: 1) Ukrainian policy documents and legal acts on anti-corruption adopted since 2014; 2) policy recommendations issued by the RPR in the years 2014-2019, the RPR roadmap for reforms, RPR reports, and the RPR website; 3) the reports, recommendations, and requirements of international actors to the Ukrainian government. We included documents on anti-corruption policy published between 2014 and 2019 by the three major international actors involved in the reform process in Ukraine: the European Union External Action Service (EEAS), the IMF, and the Organisation for Economic Development and Cooperation (OECD). Documents concerning the reforms of anti-corruption policy included EEAS project reports, IMF country reports, and the OECD Istanbul Anti-Corruption Action Plan for Ukraine and its progress reports; 4) expert reports on Ukrainian corruption policy; 5) the available secondary literature on corruption policy in Ukraine (see Appendix 1 for a list of primary documents included in the analysis).

The document analysis was triangulated with semi-structured interviews. We conducted interviews with three experts on Ukrainian anti-corruption policy. We selected the interview partners based on their knowledge of the role of the RPR and of international organisations in the Ukrainian anti-corruption policy subsystem. The three experts work for a key member NGO of the $\mathrm{RPR}$, for an international organisation collaborating with the RPR, and for an international donor providing finance to the RPR. The interviews took around one hour and were conducted over skype. The interview guidelines can be found in Appendix 2.

Operationalisation and data analysis: We drew on qualitative content analysis (Mayring, 2010, 2014) to analyse the documents and interview notes. All the texts were coded using a systematic coding scheme with deductive categories. We used the qualitative coding software MAXQDA that allows assigning parts of texts to coding categories. After coding, textual data with the same codes were re-read, interpreted, and summarised by the researchers. The development of the coding system and the interpretation of the data followed several steps: First, before the examination of our expectations, we identified all changes in Ukrainian anti-corruption policy after the Maidan through an analysis of the policies and legal acts adopted after the Maidan. Second, we documented the anticorruption policy subsystem in Ukraine before and after the Maidan, searching for actors, the cooperation among them, and their belief systems. Third, we examined the recommendations and policy goals promoted by the RPR. For expectation 1, we analysed the resources of the coalitions before and after the Maidan. For expectation 2, we first analysed the potential influence of civil society actors of the RPR on policy. To do so, we searched for evidence on the access of RPR actors to old and new policymaking venues and on the influence of civil society actors on specific policies and legal acts. To test expectation 3, we compared the recommendations of the RPR with the recommendations of the EU, IMF, and the OECD, and examined the leverage of these international actors on Ukrainian policymaking. Table 1 provides a summary of the procedures of coding and analysis.

\section{FINDINGS: THE INFLUENCE OF CIVIL SOCIETY ACTORS ON ANTI-CORRUPTION POLICY}

\section{The Maidan events}

On 21 November 2013, the Ukrainian President Yanukovych decided unexpectedly not to sign an association agreement with the European Union. A growing number of demonstrators started protesting against this decision and against other problems such as corruption or high unemployment. Organisations that supported these protests included among others the party Batkivshchyna, Ukrainian Alliance for Reforms, the right-wing organisations Svoboda and Prawdy Sector, and Ukrainian churches. On the other side, the Ukrainian government under the Party of the Regions with the support of the Communist Party of Ukraine and the Russian Block tried to suppress the protests (Shveda \& Park, 2016). The main causes for the Maidan were the indignation of citizens towards corruption, as well as police violence, and the failure to sign the association agreement with the European Union (Onuch, 2014; Shveda \& Park, 2016). The Maidan led to the end of the Yanukovych government in February 2014. 
Tab. 1: Summary of Coding Procedure

\begin{tabular}{|c|c|c|}
\hline Concepts to be operationalised & Data sources used & Categories (subcategories) of coding and analysis \\
\hline Policy change & Legal documents & $\begin{array}{ll}\text { - } & \text { New aspects in new legal acts on anti-corruption } \\
\text { - } & \text { New institutional setting in anti-corruption }\end{array}$ \\
\hline $\begin{array}{l}\text { Advocacy coalitions in anti-corruption } \\
\text { subsystem (actors, their belief systems) }\end{array}$ & $\begin{array}{l}\text { Expert reports; secondary literature; } \\
\text { KIIS opinion surveys; interview } \\
\text { questions } 1-4,9,10\end{array}$ & $\begin{array}{ll}- & \text { Actors (for/against anti-corruption reforms) } \\
\text { - } & \text { Belief systems (deep core beliefs: } \\
\text { democratisation a priority/stability a priority; } \\
\text { policy core beliefs: corruption seen as a systemic } \\
\text { problem / corruption seen as needed for business } \\
\text { operation; secondary policy beliefs: preferred } \\
\text { policy instruments)* }\end{array}$ \\
\hline $\begin{array}{l}\text { Formal legal authority of coalitions } \\
\text { (Expectation 1) }\end{array}$ & $\begin{array}{l}\text { Expert reports; secondary literature; } \\
\text { RPR annual reports; interview }\end{array}$ & $\begin{array}{l}\text { Majority in government and parliament of both } \\
\text { coalitions before after Maidan }\end{array}$ \\
\hline
\end{tabular}

questions 1, 3

\section{Expectation 2}

Access of RPR to policy venues

\begin{tabular}{|c|c|}
\hline $\begin{array}{l}\text { RPR annual reports; reports OECD, } \\
\text { EEAS, IMF; expert reports; secondary } \\
\text { literature; interview questions 1, 2, 3, } 4\end{array}$ & $\begin{array}{ll}\text { - } & \text { Openness of policymaking to civil society } \\
\text { - } & \text { New venues of policymaking } \\
\text { - } & \text { Participation of RPR in drafting policies, } \\
\text { - } & \text { Participation of RPR in roundtables, working } \\
& \text { groups, platforms, other venues }\end{array}$ \\
\hline $\begin{array}{l}\text { RPR roadmap for reform; RPR } \\
\text { reports; expert reports; policy reports; } \\
\text { secondary literature; interview } \\
\text { questions } 2,4\end{array}$ & $\begin{array}{ll}\text { - } & \text { Policies promoted by the RPR } \\
\text { - } & \text { Comparison of RPR recommendations with } \\
& \text { policies adopted after the Maidan } \\
\text { - } & \text { Participation of RPR in drafting of legal acts and } \\
\text { establishment of institutional framework }\end{array}$ \\
\hline $\begin{array}{l}\text { RPR annual reports; reports OECD, } \\
\text { grant agreements and reports IMF; } \\
\text { grant agreements and reports EEAS; }\end{array}$ & $\begin{array}{l}\text { - Comparison of RPR recommendations with } \\
\text { recommendations of international organisations } \\
\text { - Conditions in grant agreements }\end{array}$ \\
\hline
\end{tabular}
secondary literature; interview

questions 1, 2, 3, 4

*To determine the belief system of coalitions, this research mainly draws on secondary studies. We used results of interview and surveys conducted with governmental and nongovernmental actors published in Zaloznaya et al. (2018) and Grødeland (2010), as well as surveys on corruption by the Kiev International Institute of Sociology (KIIS, 2015, 2018), and expert reports (De Waal, 2016; Marusov, 2015).

\section{The Ukrainian anti-corruption policy subsystem}

Policy subsystems are defined by their substantial and territorial boundaries, as well as by the actors influencing policy in the subsystem. In the present study, the functional boundaries are those related to anti-corruption policy, while the territorial boundaries are those of Ukraine. ${ }^{4}$

Since independence, Ukraine has seen high corruption rates that have resulted in several anti-corruption reform efforts. Anticorruption reforms were initiated in the 1990s and after the Orange Revolution in 2004, but these initiatives were only insufficiently implemented and proved to be ineffective (De Waal, 2016; Grødeland 2010; Harasymiw, 2019; Marusov, 2015). The Ukrainian anti-corruption policy subsystem has involved a variety of actors ranging from governmental actors, different parties and civil society organisations to international organisations. Overall, these actors either advocate for stricter anti-corruption reforms or prefer to keep the status quo. Pro-reform actors are guided by the deep core belief that Ukraine needs to democratise, while stability is the main priority of actors in favour of the status quo. Policy core beliefs of actors in favour of stricter anti-corruption policies is shaped

4 Since the annexation of Crimea through Russia and the beginning of the war in the Donetsk and Lugansk regions in 2014, the Ukrainian government lost effective control over these areas. Therefore, the present study includes only those regions of Ukraine that are effectively controlled by the government in Kiev. 
Tab. 2: Coalitions in the Ukrainian anti-corruption sub-system before and after the Maidan

\begin{tabular}{|c|c|c|}
\hline & Before the Maidan & \\
\hline & Reform coalition & Status quo coalition \\
\hline \multirow[t]{8}{*}{ Actors } & Parties: Batkivshchyna, UDAR & President Yanukovych \\
\hline & Non-governmental organizations & Prime Minister Azarov \\
\hline & International organisations and donors & Majority of parliamentarians \\
\hline & & Parties: Party of Regions, Communist Party, Russian \\
\hline & & Block \\
\hline & & Majority of civil servants \\
\hline & After the Maidan & \\
\hline & Reform coalition & Status quo coalition \\
\hline \multirow[t]{8}{*}{ Actors } & President Poroshenko, Prime MinisterYatsenyuk & Opposition Bloc party \\
\hline & Parties: Bloc Petro Poroshenko, People's Front, Self & Part of the judiciary system \\
\hline & Reliance, Batkivshchyna & Part of civil servants \\
\hline & Majority of parliamentarians & \\
\hline & National Anti-Corruption Bureau of Ukraine & \\
\hline & Public Prosecutor Office & \\
\hline & Non-governmental organisations (including RPR & \\
\hline & International organisations and donors & \\
\hline \multirow[t]{9}{*}{ Believe system } & Deep core beliefs: & Deep core beliefs: \\
\hline & Pro-Western sentiments & Anti-Western sentiments \\
\hline & Democratisation as a priority & Stability as priority \\
\hline & Policy core beliefs: & Policy core beliefs: \\
\hline & Corruption is systemic & Corruption is not a systemic problem \\
\hline & Anti-corruption needs deep reforms & Corruption is needed to operate businesses \\
\hline & Secondary beliefs: & Fighting corruption is not a priority \\
\hline & Focus on enforcement and rapid implementation of & Secondary beliefs: \\
\hline & changes & Policy changes should not be implemented hastily \\
\hline
\end{tabular}

by the idea that corruption is a systemic problem, and therefore, strict systemic reforms are needed (Grødeland, 2010; Zaloznaya et al., 2018). Conversely, the status quo coalition's policy core beliefs include the idea that corruption is needed to operate business (Grødeland, 2010; KIIS, 2015, 2018; Marusov, 2015) (Table 2).

\section{Changes in formal legal authority after the Maidan}

The structure of these advocacy coalitions underwent large changes through the Maidan events. Most important was the redistribution of formal legal authority to make policy decisions. Anti-corruption policy in Ukraine is formulated at the national level. Laws and decrees are decided upon by the legislative (Verkhovna Rada, unicameral parliament) and the executive (president, the prime minister, and the cabinet of ministers) (Fluri and Badrack, 2016). After the Maidan, Petro Poroshenko was elected as president. His candidature was based on the support for the EU association agreement and anti-corruption reforms. His party included many Maidan and anticorruption activists and won $21.8 \%$ seats in the parliament. Together with other pro-European parties, such as People's Front and Self Reliance, Poroshenko's party achieved a majority in parliament. Moreover, the offices of the president and the prime minister, as well as the majority of the cabinet of ministers was transferred to the reform coalition. All the pro-European parties had supported anti-corruption reforms in their election campaigns (Diuk, 2014). The status quo coalition, however, lost legal authority and became the minority coalition. Before the Maidan, the presidency and parliamentary majority was in the hands of the previous dominant party, the Party of Regions. After the Maidan, the Party of the Regions was banned, and all legal authority was transferred to the reform coalition. Only a part of civil servants, members of ministries, and of the judiciary system remained in the hand of the status quo coalition (Marusov, 2016). 
This suggests that the Maidan events led to a redistribution of the formal legal authority to make policy decisions in favour of the pro-reform coalition, which the RPR was part of. Through this change, the previous minority reform coalition became the dominant coalition. Consequently, the reform coalition had the possibility to exploit the new situation to bring in their belief system into the anti-corruption policy reform. This suggests that our first expectation (Through the Maidan, the coalition that includes the civil society actors of the RPR gained legal authority to make policy decisions leading to a change in anti-corruption policy) can be confirmed.

\section{Policy change after the Maidan and the role of civil society therein}

With the newly gained legal authority to make policy decision, the new government introduced a variety of anti-corruption reforms. The new anti-corruption policy consisted of a solid legal framework including a new comprehensive strategy for combatting corruption and the creation of an institutional framework to enforce anti-corruption laws (Bratu, 2016; interview international expert 1; Law of Ukraine 'On the Principles of State Anti-Corruption Policy in Ukraine - the Anti-Corruption Strategy for 20142017'). One interviewed expert explained: 'The priority became to rewrite the national strategy on anti-corruption which included a law on anti-corruption and the creation of a new institutional framework.' (interview international expert 1). Consequently, the National Anti-Corruption Bureau of Ukraine (NABU) was created in 2014 and the National Agency on Corruption Prevention (NACP) in 2015. The NABU is a specialized agency to detect and investigate corruption in the public sector. The agency is supposed to operate independently and transparently (Bratu, 2016; Law of Ukraine 'On the National Anti-Corruption Bureau of Ukraine,' Marusov, 2015). Other important novelties were the introduction of the Prozorro online based public procurement system and of an online asset declaration system for public servants and politicians (Fluri \& Badrack, 2016; Marusov, 2015).

All these policy reforms have strongly been advocated for by the RPR. In 2014, the RPR presented a roadmap for reform addressed to the Ukrainian Parliament (RPR, 2015). The roadmap formulated four key goals of anti-corruption reforms, namely, 1) strengthening the ability to prosecute corrupt actions, 2) strengthening accountability of the public sector, 3) ensuring transparency of party finance and of private money in politics, and 4) ensuring access to public information (RPR, 2015). These four goals were accompanied by a concrete action plan proposed by the RPR for the anti-corruption reform. The action plan focused on the creation of an institutional framework for investigating and prosecuting corruption, increased transparency through asset declaration, transparent public procurement, and open access to information on budget expenditures, as well as the introduction of corruption prevention measures (RPR, 2015). This action plan strongly correlates with the policies that were adopted by the Ukrainian government.

According to our analysis of expert reports and to all our interviewees, civil society activists took the lead in the anti-corruption reform and played a crucial role in pushing the new government towards the establishment of anti-corruption institutions (Bader et al. 2019; Bratu, 2016; Harasymiw, 2019; interviews NGO expert and international experts 1, 2). As one interviewee put it: 'What the government did after the maidan was very much driven by civil society.' (interview international expert 1).

For example, the establishment of NABU encountered much resistance from President Poroshenko and was introduced only after consistent pressure from the RPR and international organizations. (Bratu, 2016; Marchevska, 2018; Zaloznaya et al., 2018). Representatives of the RPR were officially involved in the selection of the director and investigators of NABU (Bratu, 2016; interviews NGO expert, international expert 2; Sushko, 2015). Another example is the online asset declaration system that was vigorously promoted by the RPR, while the government repeatedly delayed the launch of the e-declaration system (Zaloznaya et al., 2018, p. 251 ; interview NGO expert). The online procurement system was developed in a collaboration of governmental actors, RPR experts and RPR member NGOs (interview NGO expert; Transparency International, 2017).

In order to advocate strict anti-corruption reforms inside the reform coalition, the civil society actors of the RPR needed access to policy venues. In a next step, we will examine how venue access for civil society actors of the RPR changed after the Maidan.

\section{Venue access for civil society actors}

Overall, the Maidan events created an improved environment for civil society actors and more possibilities of civil society to access policymaking (Harasymiw, 2019; Marchevska, 2018). One expert explained that the role of civil society has changed from the traditional position of observer to active participant in the policymaking process' (Bratu, 2016, p. 60). Moreover, several former 
civil society activists were voted into the parliament or became civil servants (Harasymiw, 2019; Marchevska, 2018; Sushko, 2015; Zaloznaya et al., 2018). Personal relations brought about increased access of the RPR to members of governments, parliamentarians, and civil servants (Harasymiw, 2019; interviews NGO expert, international expert 1; Marchevska, 2018; Sushko, 2015).

In addition to this informal access to policymakers, the RPR also gained access to institutionalised venues of policymaking. The cabinet of ministers established, for example, a support centre to improve dialogue with civil society (Sushko, 2015). In addition, a reform council was created that institutionalised meetings between the president, prime minister, and parliamentary committees with civil society actors (interview international expert 2; Sushko, 2015): '[the RPR] delegated one person to communicate what should be included in the draft of the law and this working group was established in an official decree by the Prime Minister.' (interview international expert 2).

NGOs, above all those organised in the RPR, were regularly invited to round tables with the government and parliamentarians (interviews NGO expert, international expert 2). Moreover, international organisations provided the RPR with access to policy discussion venues. The RPR was, for example, invited in round tables organised by the OECD or by the Group of States against Corruption (GRECO), the Council of Europe's anti-corruption body (interview international expert 1). Expert reports and all our interviewees suggest that RPR actors were directly involved as experts in the drafting of the anti-corruption legislation through access to these venues (Bratu, 2016; Fluri and Badrack, 2016; interviews NGO expert, international expert 1, international expert 2; Marusov, 2015; Sushko, 2015). As one interviewee explained: 'In October 2014 all drafts were developed and communicated with civil society organizations. Four different laws on anti-corruption were developed by the Minister of Justice: NABU, Prevention Agency, Asset Recovery Agency and Anti-Corruption Strategy for four years. This work was done together with civil society organisations and experts from abroad. A working group with different stakeholders was established and working on implementation. (...) Civil society organizations were a big part of all this work. They had made different efforts to develop these drafts before, but only when we also had this political will on the level of parliament and president this became possible.' (interview international expert 2).

Overall, our analysis suggests that civil society actors of the RPR had increased access to policy venues and used this access to influence anti-corruption policy. Thus, expectation 2 (The Maidan events increased venue access for civil society actors of the RPR) may also be confirmed.

\section{Advocacy of the PRP through international organisations}

According to our document analysis and interviews, not only civil society actors but also international organisations played a crucial role in advocating enhanced anti-corruption legislation and in pushing the new government towards the establishment of anti-corruption institutions. International organisations promoted the same stricter policies that were advocated by the RPR. Moreover, international organisations directly collaborated with the RPR to enhance their role in anti-corruption policy making and implementation.

The collaboration between the EU and the RPR was formalised in a project financed by the European Union External Action Service (EEAS) called 'Enhancement of RPR coalition' between 2016 and 2018 (EEAS, 2015). The goal of the project was to enhance reforms in Ukraine through the participation of civil society experts in policy making, in the implementation of reforms and in monitoring. Specific project objectives included advocacy for reforms, monitoring the quality of reforms as well as their implementation process, to communicate the reform agenda in society and to assist international institutions. The implementing organisations of this project were the Centre for Democracy and Rule of Law and Centre UA, both part of the RPR. The EU contribution to this project was 965,000 Euro until 2018 (EEAS, 2015).

The IMF country report published shortly after the creation of the RPR mentions at 19 instances anti-corruption recommendations (IMF, 2014). The staff report reiterates the key recommendations by the RPR, but it does not mention where the recommendations stem from. Another diagnostic report on governance and corruption published by the Government of Ukraine but prepared with the assistance of the IMF mentions the key requests of RPR: strengthening accountability of the public sector, ensuring transparency of party finance, access to public information, reducing corruption risks in procurement processes, and increasing capacities for prosecution and detection of acts of corruption. For this report, the RPR, as well as the Centre for Political and Legal Reforms, the Centre for Judicial Studies, the Anti-Corruption Action Centre, Transparency International, the Ukrainian League of Industrialists and Entrepreneurs, and the Ukrainian Legal Foundation, which are all part of the RPR, were consulted. 


\section{Sciendo}

The third monitoring round of the Istanbul Anti-Corruption Action Plan of the OECD also explains the importance of the RPR (OECD, 2015). This report notes that the active driver of anti-corruption reforms after the revolution of 2014 has been civil society, in particular the RPR. It explicitly mentions the detailed action plan proposed by the RPR. The following fourth round of monitoring of the Istanbul Anti-Corruption Action Plan uses RPR resources for its recommendations (OECD, 2018). This report mentions resistance to anti-corruption measures among business and political elites based on the RPR findings and uses the RPR evidence to assess the Anti-Corruption Strategy of Ukraine 2014-2017. The report also highlights the role of the RPR in informing the public regarding the corruption track record of applicants for public offices. In the section concerning the involvement of civil society, the report assesses positively the role of the RPR as a proactive, informed, and competent actor on anti-corruption reforms. Here, the report mentions clearly: 'It should be noted, that in the absence of the full and updated information from the Government these open sources (RPR and individual member organizations of the RPR) have been useful to the monitoring team to fill in information gaps.' (OECD, 2018, p. 24).

These reports provide evidence that the material for the policy recommendations by important international organisations was frequently provided by the RPR. Hence, the RPR not only directly influenced anti-corruption policy but also collaborated with international actors to do so.

Our analysis also indicates that the leverage of international organisations to advocate strict anti-corruption policy among Ukrainian governmental actors was crucial to promote policy change after the Maidan. Most importantly, both the EU and the IMF made the implementation of anti-corruption reforms a condition for continuous support to Ukraine (Bratu, 2016; Interviews NGO expert, international expert 1; Marchuk, 2017; Marchevska, 2018.) The EU demanded policy changes in order to implement visa liberalisation and economic cooperation and made the financial aid conditional upon anti-corruption reforms (EEAS, 2018; Interview NGO expert and international expert 1; Marchevska, 2018; Marchuk, 2017; Transparency International, 2017). The IMF made changes in anti-corruption policy a condition to release tranches of the emergency loan packages (IMF, 2014, 2015, 2016; Interviews NGO expert, international expert 1). More precisely, the IMF defined the adoption of the new public procurement and asset tracking system, the establishment of the NABU, and the institutionalisation of the prevention of corruption as conditions in their loan agreements (IMF 2014, 2015, 2016).

Thus, inside the pro-reform coalition, the RPR collaborated with international organisations to advocate for a strict anticorruption regime. The policy recommendations developed and advocated for by the RPR were also pushed by international organisations. These organisations had high leverage on the Ukrainian government, as they made the specific policies recommended by the RPR a condition for support to the Ukrainian government. Our data, thus, provides evidence for expectation 3 (Civil society actors of the RPR advocated anti-corruption policies also through international organisations, who had increased leverage to influence policy after the Maidan.)

\section{DISCUSSION}

Drawing on the ACF, this article has examined three expectations about how civil society actors of the RPR had influenced the Ukrainian anti-corruption policy in the aftermath of the Maidan. First, our data shows that, through the Maidan, the coalition that included the RPR gained the most important political resource, namely, formal legal authority to make policy decisions. This allowed the new government to adopt a comprehensive new legal framework and to create new anti-corruption institutions. Our analysis shows that the adopted anti-corruption policies were precisely those that were advocated for by the RPR. To advocate their policy recommendations, the RPR could rely on improved access to policymaking through personal contacts and access to roundtables, working groups, and newly created dialogue platforms. Third, the RPR advocated policy recommendations also through international organisations, who made the anti-corruption reforms proposed by the RPR a condition for their financial support.

An important result of our case study is that civil society organisations could influence anti-corruption policy effectively through their collaboration with international organisations. International organisations had increased leverage on the Ukrainian government after the Maidan, as the country was threatened by default and relied on international assistance. This finding is in line with another recent study on the role of civil society in Ukrainian anti-corruption policy (Harasymiw, 2019). Harasymiw speaks of a 'sandwich' strategy, where civil society organisations apply pressure on the government from below while international organisations apply pressure from above. Harasymiw argues that 'an ad hoc alliance of civil society organizations with international aid organizations 
which together have succeeded in pressuring the Ukrainian government in several instances into adopting universally accepted anticorruption measures' (Harasymiw, 2019, p. 289). Our study could confirm this 'sandwich' strategy.

However, another recent study on the role of civil society in anti-corruption reforms in Ukraine argued that, after 2016, civil society actors were deliberately excluded from anti-corruption reform venues (Zaloznaya et al., 2018). Our interviewees also explained that, after 2016, the Ukrainian government took a stronger role in anti-corruption reforms and became less accessible for anti-corruption civil actors (interviews NGO expert, international experts 1 and 2). The interviewed NGO expert argued that the role of the RPR diminished after the implementation of the first round of reforms. Also, the mission of the RPR has now shifted to coordination and training activities.

This raises the question of how sustainable and effective the Ukrainian anti-corruption reforms are. There are indications that the policy reforms have, to a certain extent, been effective (Lough and Dubrovskiy, 2018). The reforms led to a slight improvement in Ukraine's score in the Corruption Perception Index (CPI) of Transparency International. The CPI measures the perceived corruption on a scale from 1 to 100. In 2013, Ukraine reached 25 points out of 100 in the CPI. In 2019, the CPI of Ukraine was 30 points out of 100. Although this means a slight improvement, Ukraine is still only ranked 126 out of 180 countries. The experts interviewed in the framework of this study all agreed that the situation slightly improved between 2014 and 2019. According to the interviewed NGO expert, the changes of the past five years led to the establishment of a full institutional framework in the anti-corruption field. Another expert pointed to the positive changes in governmental openness and transparency, where the Ukrainian level is today comparably higher than in many other countries (interview international expert 1).

Despite these improvements, many challenges remain (Lough and Dubrovskiy, 2018). Enforceability of anti-corruption laws remains one of the most important bottlenecks of effective anti-corruption policy in Ukraine. After a phase of rapid change after the Maidan, the speed of reforms has slowed down. It remains an open question how the government Zelensky will advance in the anti-corruption field.

\section{CONCLUSIONS}

The purpose of this article was to examine how civil society actors of the RPR have influenced the Ukrainian anti-corruption policy after the Maidan events in 2014. Our analysis has shown that the Ukrainian anti-corruption policy has undergone significant changes in the past years. These changes were crucially influenced by civil society actors and the RPR especially. Most importantly, our research highlights how domestic NGOs can use international actors who have higher leverage to influence policy reforms.

These findings contribute in three ways to the ACF. First, they confirm the previous ACF research that demonstrates how a significant perturbation external to the subsystem can lead to a redistribution of resources and motivate policy change (e.g., Albright, 2011; Nohrstedt, 2011). Second, our research highlights the importance of international actors inside advocacy coalitions. While previous ACF studies have examined the role of advocacy coalitions in globalised policy issues (Litfin, 2000), the present study introduces another strand of argument by focusing on the role of international organisations inside domestic advocacy coalitions. Third, the present research focuses on the processes of advocacy among partners of the same coalition.

Despite these contributions to the ACF and to the debate on the influence of civil society in policymaking, this study also has limitations to address. First, these results have been deduced from one single case in the specific context of Ukraine. Second, the case study includes only three interviews. To address this limitation, we triangulated interviews with a systematic document analysis. Also, the interviewed experts were selected based on their thorough knowledge of the Ukrainian anti-corruption policy subsystem. Therefore, further investigations are needed into the relationship between governments, civil society organisations, and international actors. 


\section{REFERENCES}

Albright, E. A. (2011). Policy change and learning in response to extreme flood events in Hungary: an advocacy coalition approach. Policy Studies Journal, 39(3), 485-511.

Abdulai, A. G. (2009). Political will in combating corruption in developing and transition economies. Journal of Financial Crime. 16(4), 387-417.

Bader, M., Huss, O., Meleshevich, A., \& Nesterenko, O. (2019). Civil Society Against Corruption in Ukraine: Pathways to Impact. Kyiv-Mohyla Law and Politics Journal, 5(2019), 1-35.

Bennett, A. (2004). Case study methods: Design, use, and comparative advantages. In Models, numbers, and cases: Methods for studying international relations. Sprinz, D.F. \& Nahmias-Wolinsky, Y. (eds). Ann Arbor: Univerity of Michigan Press, 19-55.

Bratu, R. (2016). Living on the edge: Ukraine's ambiguous war on corruption. NATO Science for Peace and Security Series,-E: Human and Societal Dynamics, 129, 57-64.

Denisova-Schmidt, E., Huber, M, Leontyeva, E. (2016) Do AntiCorruption Educational Campaigns Reach Students? Voprosy obrazovaniya, 2016(1), 61-83.

De Sousa, L., Hindess, B., \& Larmour, P. (Eds.). (2012). Governments, NGOs and Anti-Corruption: the new integrity warriors. New York: Routledge.

De Waal, T., (2016), Fighting a Culture of Corruption in Ukraine, Carnegie Europe, Retrieved from https://carnegieendowment.org/files/ Fighting_a_Culture_of_Corruption_in_Ukraine_deWaal.pdf.

Diuk, N. (2014). The Maidan and Beyond: Finding Ukraine. Journal of Democracy, 25(3), 83-89.

European Union External Action Service EEAS. (2018). Association Implementation Report on Ukraine. Kyiv: EEAS. https://eeas.europa. eu/headquarters/headquarters-homepage/53485/associationimplementation-report-ukraine_en

European Union External Action Service EEAS. (2015). Enhancement of RPR coalition. Kyiv: EEAS. Retrieved from https://eeas.europa. eu/delegations/ukraine_en/27143/Enhancement\%20of\%20RPR\%20 coalition .

European Union External Action Service EEAS. (2014), Ukraine EU Country Roadmap for Engagement with Civil Society 2014-2017, https://eeas. europa.eu/sites/eeas/files/ukraine_civil_society_roadmap_2014.pdf .

Fang, S., \& Stone, R. W. (2012). International organizations as policy advisors. International organization, 66(4), 537-569.
Fluri, Philipp and Valentyn Badrack (eds.) (2016). Anti-Corruption Measures in Ukraine After the Revolution ofDignity Key Legislative Aspects. Geneva: Center for Army, Conversion and Disarmament Studies.

Fritzen, S. (2005). Beyond "political will": How institutional context shapes the implementation of anti-corruption policies. Policy and Society, 24(3), 79-96.

George, Alexander, and Andrew Bennett. 2004. Case Studies and Theory Development in the Social Sciences. Cambridge: Cambridge University Press.

Gerring, J. (2007). Case Study Research. Principles and Practices. New York: Cambridge University Press

Grimes, M. (2013). The contingencies of societal accountability: Examining the link between civil society and good government. Studies in Comparative International Development, 48(4), 380-402.

Government of Ukraine. (2014). Report on Diagnostic Study of Governance Issues Pertaining to Corruption, the Business Climate and the Effectiveness of the Judiciary Prepared with the Assistance of the Legal Department of the International Monetary Fund. Kyiv: Government of Ukraine. Retrieved from: https://www.imf.org/external/ pubs/ft/scr/2014/cr14263-a.pdf.

Grødeland, Å. B. (2010). Elite perceptions of anti-corruption efforts in Ukraine. Global Crime, 11(2), 237-26o.

Harasymiw, B. (2019). Civil society as an anti-corruption actor in postEuromaidan Ukraine. Canadian Slavonic Papers, 61(3), 288-320.

Heinmiller, B. T. (2013). Advocacy Coalitions and the Alberta "Water Act". Canadian Journal of Political Science/Revue canadienne de science politique, 525-547.

Heinmiller, B. T. (2016). Water policy reform in southern Alberta: an advocacy coalition approach. Toronto: University of Toronto Press.

Heineman Jr, B. W., \& Heimann, F. (2006). The long war against corruption. Foreign Affairs, 85, 75-86.

Hirschi, C., \& Widmer, T. (2010). Policy change and policy stasis: Comparing swiss foreign policy toward South Africa (1968-94) and Iraq (1990-91). Policy Studies Journal, 38(3), 537-563.

International Monetary Fund IMF. (2014) IMF Country Report 14/106. Washington: IMF. https://www.imf.org/en/Publications/ CR/Issues/2016/12/31/Ukraine-Request-for-A-Stand-ByArrangement-41516. 
International Monetary Fund IMF. (2015). Ukraine: Request for Extended Arrangement Under the Extended Fund Facility and Cancellation of Stand-By Arrangement. https://www.imf.org/en/Publications/CR/ Issues/2016/12/31/Ukraine-Request-for-Extended-Arrangement-Underthe-Extended-Fund-Facility-and-Cancellation-42778

International Monetary Fund IMF. (2016). Ukraine: 2016 Article IV Consultation and third review under the Extended Arrangement. https://www.imf.org/en/Publications/CR/Issues/2017/04/04/Ukraine2016-Article-IV-Consultation-and-third-review-under-the-ExtendedArrangement-44798

Jenkins-Smith, H. C., \& Sabatier, P. A. (1994). Evaluating the advocacy coalition framework. Journal of Public Policy, 14(2), 175-203.

Jenkins-Smith, H. C., Nohrstedt, D., Weible, C. M., \& Ingold, K. (2018). The Advocacy Coalition Framework: An Overview of the Research Program. In Theories of the Policy Process, eds. Weible, C.M., Sabatier, P.A. (eds.). Boulder, CO: Westview Press, 135-171.

Kübler, D. (2001). Understanding policy change with the advocacy coalition framework: an application to Swiss drug policy. Journal of European public policy, 8(4), 623-641.

Kukkonen, A., Ylä-Anttila, T., Swarnakar, P., Broadbent, J., Lahsen, M., \& Stoddart, M. C. (2018). International organizations, advocacy coalitions, and domestication of global norms: Debates on climate change in Canada, the US, Brazil, and India. Environmental Science \& Policy, 81, 54-62.

Kyivs'kyi mizhnarodnyi instytut sotsiolohii (KIIS). (2018). Dumky i pohliady naselennia Ukrainy: lystopad-hruden'2018 roku: analitychnyi zvit. Kyiv: Kyivs'kyi mizhnarodnyi instytut sotsiolohii.

Kyivs'kyi mizhnarodnyi instytut sotsiolohii (KIIS). (2015). Corruption in Ukraine. Comparative analysis of national surveys: 2007, 2009, 2011, and 2015. Kyiv: Kyivs'kyi mizhnarodnyi instytut sotsiolohii.

Litfin, K. T. (2000). Advocacy coalitions along the domestic-foreign frontier: Globalization and Canadian climate change policy. Policy Studies Journal, 28(1), 236-252.

Lough, J., \& Dubrovskiy, V. (2018). Are Ukraine's Anti-corruption Reforms Working?. London: Chatham House.

Marchevska, Denitsa. (2018). Participatory Governance in Ukraine - an Ongoing Struggle. A Case Study of Anti-Corruption Policy-Making since 2014. Master's Thesis Leiden Univerity.

Marchuk, M. (2017). Anticorruption in Ukraine: Unbiased Overview, Kyiv: Vox Ukraine.

Marusov, Andrii. (2016). Anti-Corruption Policy of Ukraine: First Successes and Growing Resistance: PolicyReport. International Renaissance and Open Societies Foundations.
Mayring, P. (2010). Qualitative inhaltsanalyse. In Mey, G. \& Mruck, K. (eds).

Handbuch qualitative Forschung in der Psychologie (pp. 601-613). Wiesbaden: Springer.

Mayring, P. (2014). Qualitative content analysis: theoretical foundation, basic procedures and software solution. Klagenfurt. https://nbnresolving.org/urn:nbn:de:0168-ssoar-395173

Mungiu-Pippidi, A. (2010). The experience of civil society as an anticorruption actor in East Central Europe. Romanian Journal of Political Sciences, (02), 5-33.

Mungiu-Pippidi, A. (2015). The quest for good governance: How societies develop control of corruption. Cambridge: Cambridge University Press.

Nohrstedt D. (2011). Shifting resources and venues producing policy change in contested subsystems: A case study of Swedish signals intelligence policy. Policy Studies Journal, 39(3), 461-484.

Onuch, O. (2014). The Maidan and Beyond: Who were the protesters? Journal of Democracy, 25(3), 44-51.

Organisation for Economic Co-Operation and Development OECD. (2015). Anti-Corruption Reforms in Ukraine, Round 3 Monitoring of the Istanbul Anti-Corruption Action Plan. Paris: OECD. Retrieved from: https://www.oecd.org/daf/anti-bribery/Ukraine-Round-3-MonitoringReport-ENG.pdf.

Organisation for Economic Co-Operation and Development OECD. (2018). Anti-corruption reforms in Ukraine 4 th round of monitoring of the Istanbul Anti-Corruption Action Plan. Paris: OECD. Retrieved from: https://www.oecd.org/corruption/acn/OECD-ACN-4th-Round-ReportUkraine-Progress-Update-July-2018-ENG.pdf

Persson, A., Rothstein, B., \& Teorell, J. (2013). Why anticorruption reforms fail-systemic corruption as a collective action problem. Governance, 26(3), 449-471.

Poljak, Ž. (2018). Advocacy coalitions in transport policy: a case of rail sector in Croatia. Central European Journal of Public Policy, 12(1), 41-56.

Reanimation Package of Reforms RPR. (2015). Roadmap of Reforms. Kyiv: RPR. Retrieved from: http://rpr.org.ua/wp-content/ uploads/2016/12/Roadmap_of_Reforms_-_2015.pdf.

Sabatier, P. A. (1987). Knowledge, policy-oriented learning, and policy change: An advocacy coalition framework. Knowledge, 8(4), 649-692.

Sabatier, P., \& Weible, C. 2007. 'The Advocacy Coalition: Innovations and Clarifications.' In Theories of the Policy Process, 2nd ed., Paul Sabatier (ed.). Boulder, CO: Westview Press, 189-220. 
Seawright, J., \& Gerring, J. (2008). Case selection techniques in case study research: A menu of qualitative and quantitative options. Political research quarterly, 61(2), 294-308.

Schlaufer, C. (2019). How does policy advice of the International Monetary Fund differ along the income of advised countries?. Policy Studies, 40(3-4), 287-302.

Stapenhurst, F., \& Langseth, P. (1997). The role of the public administration in fighting corruption. International Journal of Public Sector Management.

Shveda, Y., \& Park, J. H. (2016). Ukraine's revolution of dignity: The dynamics of Euromaidan. Journal of Eurasian Studies, 7(1), 85-91.

Transparency International Ukraine (2017). Co-creation of Prozorro. An account of the process and actors. Kyiv: Transparency International Ukraine. https://www.transparency.org/en/publications/co-creation-ofprozorro-an-account-of-the-process-and-actors

Weible, C. M., Ingold, K., Nohrstedt, D., Henry, A. D., \& Jenkins-Smith, H. C. (2019). Sharpening advocacy coalitions. Policy Studies Journal. Early online.

Zaloznaya, M., Reisinger, W. M., \& Claypool, V. H. (2018). When civil engagement is part of the problem: Flawed anti-corruptionism in Russia and Ukraine. Communist and Post-Communist Studies, 51(3), 245-255. 


\section{APPENDIX 1. PRIMARY DOCUMENTS INCLUDED IN THE ANALYSIS}

\section{Policy documents}

Law of Ukraine "On the Principles of State Anti-Corruption Policy in Ukraine (the Anti-Corruption Strategy) for 2014-2017"

Law of Ukraine "On Preventing Corruption”

Law of Ukraine "On the National Anti-Corruption Bureau of Ukraine"

Law of Ukraine "On the State Bureau of Investigation of Ukraine"

The Cabinet of Ministers of Ukraine Resolution "On Establishment of the National Agency for Prevention of Corruption"

The Cabinet of Ministers of Ukraine Resolution "Certain issues of selection of candidates for the positions of members of the National Agency for Prevention of Corruption"

Government of Ukraine. (2014). Report on Diagnostic Study of Governance Issues Pertaining to Corruption, the Business Climate and the Effectiveness of the Judiciary Prepared with the Assistance of the Legal Department of the International Monetary Fund. Kyiv: Government of Ukraine. https://www.imf.org/external/pubs/ft/scr/2014/cr14263-a.pdf.

\section{Expert and NGO reports, opinion surveys}

Bratu, R. (2016). Living on the edge: Ukraine's ambiguous war on corruption. NATO Science for Peace and Security Series. : Human and Societal Dynamics, 129, 57-64.

De Waal, T., (2016), Fighting a Culture of Corruption in Ukraine, Carnegie Europe. https://carnegieeurope.eu/2016/04/18/fightingculture-of-corruption-in-ukraine-pub-63364

Fluri, P. and V. Badrack. (2016). Anti-Corruption Measures in Ukraine After the Revolution of Dignity Key Legislative Aspects. Geneva: Center for Army, Conversion and Disarmament Studies.

Kyivs'kyi mizhnarodnyi instytut sotsiolohii (KIIS). Dumky i pohliady naselennia Ukrainy: lystopad-hruden'2018 roku: analitychnyi zvit. Kyiv: Kyivs'kyi mizhnarodnyi instytut sotsiolohii, December 2018.

Kyivs'kyi mizhnarodnyi instytut sotsiolohii (KIIS). 2015. Corruption in Ukraine. Comparative analysis of national surveys: 2007, 2009, 2011, and 2015. Kyiv: Kyivs'kyi mizhnarodnyi instytut sotsiolohii.

Lough, J., \& Dubrovskiy, V. (2018). Are Ukraine’s Anti-corruption Reforms Working?. London: Chatham House.

Marusov, A. (2016). Anti-Corruption Policy of Ukraine: First Successes and Growing Resistance: PolicyReport. International Renaissance and Open Societies Foundations.

Reanimation Package of Reforms RPR. (2015). Roadmap of Reforms for 2015.http://rpr.org.ua/wp-content/uploads/2016/12/ Roadmap_of_Reforms_-_2015.pdf.

Reanimation Package of Reforms RPR. (2016). Roadmap of Reforms for 2016-2017. 
https://rpr.org.ua/wp-content/uploads/2016/09/RPR-Roadmap-of-Reforms-for-Ukraine.pdf

Reanimation Package of Reforms RPR. (2016). RPR strategy for 2016-2017. https://rpr.org.ua/en/rpr-strategy/

Reanimation Package of Reforms RPR. (2016). Annual Report 2015. https://rpr.org.ua/en/annual-reports/

Reanimation Package of Reforms RPR. (n.d). Achievements of the RPR Coalition for the last 5 years. https://rpr.org.ua/en/ achievements/

Reanimation Package of Reforms RPR. (2017). Reforms under the microscope. https://rpr.org.ua/en/reforms-under-the-microscope/

Sushko, O.. (2015). Reforming Ukraine: Policymaking After the Euromaidan.” Ponars Eurasia.

Transparency International Ukraine (2017). Co-creation of Prozorro. An account of the process and actors. Kyiv: Transparency International Ukraine. https://www.transparency.org/en/publications/co-creation-of-prozorro-an-account-of-the-process-and-actors

\section{Reports international organizations}

European Union External Action Service EEAS. (2018). Association Implementation Report on Ukraine. Kyiv: EEAS. https://eeas. europa.eu/headquarters/headquarters-homepage/53485/association-implementation-report-ukraine_en

European Union External Action Service EEAS. (2015). Enhancement of RPR coalition. Kyiv: EEAS. https://eeas.europa.eu/ delegations/ukraine_en/27143/Enhancement\%20of\%20RPR\%20coalition

European Union External Action Service EEAS. (2014). Ukraine EU Country Roadmap for Engagement with Civil Society 20142017, https://eeas.europa.eu/sites/eeas/files/ukraine_civil_society_roadmap_2014.pdf

International Monetary Fund IMF. (2014) IMF Country Report 14/106. Washington: IMF. https://www.imf.org/en/Publications/ CR/Issues/2016/12/31/Ukraine-Request-for-A-Stand-By-Arrangement-41516.

International Monetary Fund IMF. (2014). Ukraine: Request for A Stand-By Arrangement.

https:/www.imf.org/en/Publications/CR/Issues/2016/12/31/Ukraine-Request-for-A-Stand-By-Arrangement-41516

International Monetary Fund IMF. (2015). Ukraine: Request for Extended Arrangement Under the Extended Fund Facility and Cancellation of Stand-By Arrangement. https:/www.imf.org/en/Publications/CR/Issues/2016/12/31/Ukraine-Request-forExtended-Arrangement-Under-the-Extended-Fund-Facility-and-Cancellation-42778

International Monetary Fund IMF. (2015). Ukraine: First Review Under the Extended Arrangement. https://www.imf.org/en/ Publications/CR/Issues/2016/12/31/Ukraine-First-Review-Under-the-Extended-Arrangement-Press-Release-Staff-Report-andStatement-43152

International Monetary Fund IMF. (2016). Ukraine: Technical Assistance Report-Reforming Management and Oversight of State Assets. https:/www.imf.org/en/Publications/CR/Issues/2016/12/31/Ukraine-Technical-Assistance-Report-ReformingManagement-and-Oversight-of-State-Assets-43663

International Monetary Fund IMF. (2016). Ukraine: Second Review Under the Extended Fund Facility and Requests for Waivers of 
Non-Observance of Performance Criteria, Rephasing of Access and Financing Assurances.

https://www.imf.org/en/Publications/CR/Issues/2016/12/31/Ukraine-Second-Review-Under-the-Extended-Fund-Facility-andRequests-for-Waivers-of-Non-44318

International Monetary Fund IMF. (2016). Ukraine: 2016 Article IV Consultation and third review under the Extended Arrangement. https:/www.imf.org/en/Publications/CR/Issues/2017/04/04/Ukraine-2016-Article-IV-Consultation-and-third-review-under-theExtended-Arrangement-44798

Organisation for Economic Co-Operation and Development OECD. (2015). Anti-Corruption Reforms in Ukraine, Round 3 Monitoring of the Istanbul Anti-Corruption Action Plan. Paris: OECD. Retrieved from: https://www.oecd.org/daf/anti-bribery/ Ukraine-Round-3-Monitoring-Report-ENG.pdf .

Organisation for Economic Co-Operation and Development OECD. (2018). Anti-corruption reforms in Ukraine 4th round of monitoring of the Istanbul Anti-Corruption Action Plan. Paris: OECD. Retrieved from: https:/www.oecd.org/corruption/acn/ OECD-ACN-4th-Round-Report-Ukraine-Progress-Update-July-2018-ENG.pdf

\section{APPENDIX 2. QUESTIONS FOR SEMI-STRUCTURED INTERVIEWS}

1) How do you see the role of the government in the fight against corruption?

2) How do you see the role of the civil society in the fight against corruption?

3) How do you see the role of international actors (EU, IMF) in the fight against corruption?

4) What do you associate with the Reanimation Package of Reforms?

5) Do you think the reforms since 2015 have significantly reduced corruption in Ukraine? If so, why? If not, why not?

6) What do you perceive as the biggest problem in the fight against corruption?

7) Please rate the level of corruption in 2019 on a scale from 1 (low) to 10 high.

8) Please rate the level of corruption in 2013 on a scale from 1 (low) to 10 (high).

9) How do you see the role of the National Anti-Corruption Bureau of Ukraine in the fight against corruption?

10) If you alone could change one thing about the anti-corruption policy, what would you change? And why? 